\title{
Ammatista portfolioon
}

Anja Heikkinen \&

kump. (2001). Niin vä-

hän on aikaa - amma-

tillisen kasvun aika,

paikka ja tila? Ammat-

tikasvatuksen tutkimus-

ja koulutuskeskus,

Tampereen yliopisto.

\section{AMKER-projektiryhmän}

kolmas väliraportti "Niin vähän on aikaa - ammatillisen kasvun aika, paikka ja tila?" antaa monipuolisen ja eritellyn kuvan siitä, miten suomalaiset työelämän toimijat kokevat ja käsittävät työnsä, ammattinsa ja ammatillisen kasvunsa muutoksen. Tulkinta on teoreettisesti perusteltu ja antaa kuitenkin äänen tutkimuskohteena oleville ihmisille. Tämä "alhaalta" tuleva näkökulma suhteutetaan kriittisesti "ylhäältä" tulevaan ammatillisen koulutuksen julkisen perustelemisen, suunnittelemisen ja organisoimisen perspektiiviin. Tuloksena on tarkastelu, joka kyseenalaistaa tärkeällä tavalla ammattikasvatuksen itsestäänselvyyksiä.

\section{Keskityn tässä juuri} raportin itsestäänselvyyksiä kyseenalaistavaan pyrkimykseen. ${ }^{1}$ Pidän sitä erityisen tärkeänä siksi, että koulutuksen nimeen vannotaan nykyisin joka taholla. Koulutus näyttää niin erinomaiselta vastaukselta, että se samalla tuntuu automaattisesti legitimoivan ne kysymykset, joiden vastaukseksi se soveltuu. Hallitsevaksi, agendaa määritteleväksi kysymykseksi on 1980-luvulta lähtien noussut kilpailukyky globalisoituvassa taloudessa.
Olennaista on, että kyse ei ole pelkästään yritysten kilpailukyvystä, vaan myös siitä, miten eritasoiset yhteisöt paikalliset, alueelliset, kansalliset yhteisöt ja Euroopan yhteisö - tekevät itsensä kilpailukykyisiksi kilpailussa investoinneista, tuotannon ja työpaikkojen sijainnista. Näiden yhteisöjen, edelleen hyvin vahvasti nimenomaan kansallisvaltioiden, on tehtävä itsensä houkutteleviksi sen ylikansallisen päätöksenteon edessä, joka ohjaa rahavirtoja, investointeja, tuotannon ja työpaikkojen sijaintia. Kaikissa OECD-maissa tieto, koulutus ja osaaminen esitetään kilpailukyvyn keskeisenä edellytyksenä ja aineksena.

\section{Asiasta vallitsee ainakin} periaatteessa suuri yhteisymmärrys. Esimerkiksi EU:n tasolla työnantaja- ja työntekijäjärjestöjen "sosiaalisessa vuoropuhelussa" on tästä kysymyksestä 1990-luvulla saatu aikaan varsin vaivattomasti yhteisiä kannanottoja. Taloudellista kilpailukykyä haetaan osaamisen ja innovatiivisuuden tietä vaihtoehtona mataliin palkkoihin ja sosiaalietuuksien karsimiseen perustuvalle kilpailukyvylle. Tätä myös ammattiyhdistysliikkeen on ollut helppo kannattaa.

\section{Ammattiyhdistysliike on} eri Pohjoismaissa ja myös pohjoismaisen ja eurooppalaisen yhteistyön tasolla etsinyt itselleen paikkaa uusissa ammattitaito- ja koulutuskysymyksiin tai, kuten nykyisin pitää sanoa, kompetenssin kehittämiseen keskittyvissä yri- tysten, paikkakuntien, kansakuntien ja Euroopan kilpailustrategioissa. Merkitystä on myös sillä, että koulutusta korostamalla kansallisvaltion aktiivinen rooli on voitu yhdistää vapaan markkinatalouden vaalimiseen. Koulutusteeman yhteydessä on myös voitu pitää kiinni hyvinvointivaltion rakentamisvaiheessa laajalti omaksutusta näkemyksestä, jonka mukaan taloudellisen kasvun, työllisyyden ja sosiaalisen kiinteyden välillä vallitsee itseään vahvistava hyvä kehä.

\section{Kaiken kaikkiaan}

koulutuksen nykykorostuksissa on paljon sellaista, mikä vetoaa tuttuihin ja melko pysyviin ajattelutapoihin ja tukee niitä. Mutta - ja tälle pohdinnalle AMKER-raportti tarjoaa runsaasti tietoa ja virikettä - niissä on paradoksaalisesti myös paljon sellaista, missä koulutus näyttäytyy jyrkkänä rajanvetona menneisyyteen. Koulutus kytketään vapaiden markkinoiden, kilpailun ja joustavuuden puolestapuhumiseen. Taloudellinen globalisaatio on ruokkinut vaikutusvaltaisten toimijoiden yhteisymmärrystä siitä, että yhteiskunnan olisi oltava ytimeltään "kansallinen innovaatiojärjestelmä", kuten melko uusi muotitermi kuuluu. Tästä näkökulmasta, innovatiivisen kilpailukyvyn tavoitteenasettelusta määrittyvänä toimintana, koulutuksesta on tullut menneestä irtautumisen tunnus.

\section{Käsittääkseni AMKER-} raportin tärkeä pohdinta am- 
matillisen kasvun ja elinikäisen oppimisen periaatteiden ristiriidasta liittyy juuri tähän koulutuksen uuteen merkitykseen ja kontekstiin. Tutkijaryhmä korostaa, ettei kysymys ole siitä, että uudesta vinhasti muuttuvasta teknologiasta automaattisesti seuraisi ammatti-identiteettien heikentyminen ja elinikäisen oppimisen vaatimuksen vahvistuminen. Ryhmä on tehnyt ansiokkaan pesäeron teknologiseen determinismiin ja funktionalismiin, näkemyksiin, joiden mukaan ammattikasvatus on muotoutunut välttämättöminä vastauksina teknologian omalakisen kehityksen tai teollisen modernisaation tuomiin ongelmiin. Niin merkittävä kuin tietotekninen mullistus onkin ollut, sen merkitykset ovat muotoutuneet talouden organisointitapojen muutosten yhteydessä - markkinoiden vapauttamisen yhteydessä, kapitalismin muodostuessa maailmanlaajuiseksi järjestelmäksi vailla varteenotettavia haastajia. Se, miten markkinakilpailun logiikka on muovannut työsuhteita, työtä ja työntekijöitä, on tässä merkittävää. Haluaisin ottaa esiin muutamia näkökohtia juuri tästä teemasta.

\section{Kuvatessaan muutosta} projektiryhmä lähtee ammatin kaksinaiskytkennästä toisaalta persoonalliseen identiteettiin, toisaalta yhteiskunnalliseen kokonaistyönjakoon. $\mathrm{Ku}-$ vaa konkretisoidaan esimerkiksi siihen, miten ammatillinen kasvu toteutui puunjalostustehtaissa ja tehdasyhteisöissä tai sairaalayhteisöissä. Jos tähän sovellettaisiin sosiaaliantropologi Mary Douglasin tekemää jakoa hierarkian, yhteisön ja markkinoiden periaatteisiin, voitaisiin sanoa, että tässä ammatti-identiteettien muodostumisen historiallisessa kuvassa näkyvät ennen muuta yhteisö ja hierarkia. Olen tämän kuvan suhteen hieman kriittinen, koska käsittääkseni ammatti on ollut vanhastaan myös markkinalogiikan asia. Ammatti on viitannut sekä asemaan tuotantoprosessin toimijana että asemaan työmarkkinoiden toimijana. Erityisen helppoa tämä on ollut havaita alalla, johon raportissa ei juuri puututa, nimittäin rakennusalalla. Työt ovat olleet kausiluonteisia ja työsuhteet lyhytaikaisia, mutta samaan aikaan ammattiidentiteetit, nimenomaan ammattimiesten, ovat olleet varsin selvärajaisia ja saaneet voimaa työmarkkinoiden hallinnasta. Olennaista on joka tapauksessa se, että markkinalogiikan toimintatavat ovat muuttuneet.

\section{Raportin antamien}

virikkeiden pohjalta tämä muutos voidaan ilmaista sanomalla, että ammatin tilalle tulee portfolio. Näin tuntuu käyvän siitäkin huolimatta, että Leena Kuusiston haastattelema tekstiilialan toimitusjohtaja suhtautui epäluuloisesti oppilaitosvierailulla näkemiinsä portfolioihin: "Mää niinkun mietin, että mitä ihmettä täällä kaikki ihmiset vaan hakkaa tietokonetta ja tekee portfolioita ja niillä on vaan hauskaa ja kivaa ja ne vaan luo jotakin, jolla ei oo edes mitään päämäärää.” (Niin vähän on aikaa, s. 74). Omaa osaamista esittelevän portfolion yhteys "itseen" on toisenlainen kuin ammatin. Se vaa- tii jatkuvaa päivittämistä. Tässä on kyse enemmästä kuin vain siitä, että työtodistukset on ennenkin pitänyt pitää ajan tasalla. Portfolion kuuluu olla todiste ei vain kokemuksista vaan myös odotuksista, elinikäisen oppijan ominaisuudesta. Ammatin ja ammatti-identiteetin sosiaalisesta ja kollektiivisesta luonteesta portfolio poikkeaa myös siinä, että se on toisella tavoin yhtä aikaa henkilökohtainen ja itseen etäisyyttä ottava. Tämä on osaltaan sitä, mitä jotkut sosiologit ovat kuvanneet puhumalla refleksiivisestä modernisaatiosta.

\section{Oman yksilöllisen}

kilpailukyvyn vaaliminen on merkittävä refleksiivisyyden muoto. On pyrittävä osoittamaan toisille - työnantajille oma näyttö- ja käyttöarvo. On pystyttävä asettumaan kuvitteellisesti niiden asemaan, jotka kulloinkin vertailevat yksilöllisiä kilpailukykyjä. Mutta tärkeätä on huomata, että kaikessa tässä on vahvasti mukana myös yhteisön ajatus. Yksilöllinen kilpailukyky tarkoittaa kilpailukykyisen yhteisön täyttä jäsenyyttä, olipa tuo yhteisö sitten työyhteisö, paikallisyhteisö, Suomi tai Eurooppa. Monikon ensimmäinen persoona esiintyy vahvasti puhuttaessa kilpailukyvystä; se on "meidän" kilpailukykyämme, ja kilpailua käydään siitä, kuka saa kuulua "meihin". Yksilöllisen kilpailukyvyn olennaiseksi ainekseksi muodostuu taito ja tahto tarkkailla omaa toimintaa organisaation - yrityksen, toimipaikan, työyhteisön kilpailukyvyn kannalta.

On tietysti muistettava, että esimerkiksi maaseudun 
tehdasyhteisöissä työntekijöiden eläminen oli hyvin kouraantuntuvasti sidoksissa yhtiön menestykseen ja että paternalistisia paikallisyhteisöjään rakentaneet puunjalostusyhtiöt olivat myös erittäin kansainvälisiä, osallisia ankarassa kilpailussa vientimarkkinoilla. Kuitenkin työntekijän ja organisaation sidos muodostuu nyt paljon konkreettisemmin kilpailukyvyn vaatimusten pohjalta. Kykyä tarkastella omaa työtä yrityksen tai tuotantoyksikön kilpailukyvyn ja sen paikallisten ja kansallisten edellytysten kannalta vaaditaan ilmeisimmin yritysjohtajilta. On kuitenkin nähtävissä, että tästä kyvystä tulee yhä enemmän myös henkilöstön kompetenssivaatimus ja ehto yksilön kilpailukyvylle työmarkkinoilla. Tätä kykyä kehitetään työorganisaatioissa esimerkiksi erilaisilla "suoran osallistumisen" käytännöillä. Tämähän tarkoittaa toimintamuotoja, joilla työntekijät osallistuvat työorganisaation toiminnan arviointiin (esimerkiksi laatupiirit), mutta myös itse työorganisaatioon kuuluvaa työntekijöiden omaa työtehtävää koskevaa yksilöllistä ja kollektiivista itsemääräämistä ja itsevastuuta (esimerkiksi itseohjautuvat työryhmät). Jollei työntekijä ole kykenevä tai halukas aktiivisesti omaksumaan näitä toimintaehtoja, häntä uhkaa joutuminen sivuraiteelle tai kokonaan syrjään.

Tieto ja osaaminen voivat siis olla perusteina yhteisölle - eritasoisille yhteisöille työyhteisöstä Euroopan yhteisöön - mutta samalla myös yhteisön tosi jäsenyydestä ulossulkemiselle. Tässä suh- teessa kiinnostavaa on se, mitä raportissa puhutaan työn ja ammatin liitynnästä elämismaailman perspektiiviin. "Elämismaailman" käsitteellähän on viime vuosikymmeninä tunnetuimmin operoinut saksalainen yhteiskuntafilosofi Jürgen Habermas, joka on "kommunikatiivisen toiminnan" teoriassaan pohtinut "elämismaailman" ja "järjestelmän" suhdetta. Habermasin teoriassa elämismaailma noudattaa "kommunikatiivista rationaalisuutta", järjestelmä taas "instrumentaalista tai funktionalistista rationaalisuutta”, mutta järjestelmällä taloudella ja hallinnolla - on taipumuksena kolonisoida elämismaailmaa tunkemalla sen piiriin omaa instrumentaalista rationaalisuuttaan. Äkkipäätä katsoen työelämän nykymuutokset näyttävät itse asiassa aivan vastakkaisilta kuin Habermasin kolonisaatioteesi edellyttää. Norjan suurta kansallista työelämän kehittämisohjelmaa 1990-luvulla vetänyt filosofi Björn Gustavsen on puhunut työelämän kommunikatiivisesta käänteestä. Toisin sanoen elämismaailma näyttääkin kolonisoivan järjestelmää; kommunikatiivinen järki näyttää tunkeutuvan talouden ja hallinnon alueelle. Hierarkioita madalletaan, vaaditaan oman työn laaja-alaista reflektointia ja suoraa osallistumista; tämä on uusien human resourcemanagement-oppien sanomaa. Eikö tässä ole kyse tuollaisesta kommunikatiivisesta käänteestä? Syvemmälle katsottaessa tämä muutos merkitsee kuitenkin järjestelmän rationaalisuuden uusia toimintatapoja ja myös elämismaailman kolonisoinnin uusia muotoja globalisoituvassa taloudessa.

\section{Ammatillisen kasvun} problematiikan kannalta kiinnostavaa on markkinoiden ja yhteisön yhdistelmä. Markkinakilpailun sanoma ja yhteisön idea eivät selvästikään sulje pois toisiaan. Rajuja jännitteitä tämä yhdistelmä kuitenkin sisältää. Ne nousevat esiin myös työelämän toimijoiden oman elämänhallinnan näkökulmasta, siis siitä näkökulmasta, jota AMKER-raportin tutkimusartikkelit monipuolisesti valaisevat.

Yksi jännite on se, että kilpailukyky-yhteisö sisältää vahvojen ja heikkojen, voittajien ja häviäjien, rajan vahvistamisen mekanismeja. Yhteisö ottaa sisäänsä ja sulkee ulos. Tasa-arvolla näyttää olevan tältä kannalta pohjoismaisissa keskusteluissa paradoksaalinen merkitys. Työelämän osallistumiskäytännöt, myös ammattiyhdistysten ja luottamusmiesten osallisuus, hyväksytään suhteellisen laajalti ja egalitaarisia traditioita pidetään kansallisen kilpailukyvyn edellytyksinä. Kilpailukyvyn sisältöi$n \ddot{a}$ korostuvat kuitenkin sellaiset yksilön ja organisaation suhdetta koskevat ominaisuudet, jotka vaativat yksilöä tarkkailemaan aiempaa määrätietoisemmin omaa yksilöllistä kilpailukykyään kilpailukykyisen yhteisön kommunikatiivisena ja innovatiivisena jäsenenä. Merkitystä tosin on sillä, muovautuvatko yksilön mahdollisuudet tehdä itsensä kilpailukykyiseksi enemmän vai vähemmän tasa-arvoisessa koulutusjärjestelmässä. Toisaalta ammatillinen koulutus on saanut uusia merkityksiä, paitsi innovatiivisen yhteisön 
ja asiantuntijuuden vahvistajana, myös toimintana, joka sääntelee työttömyysjaksojen, kurssien ja pätkätöiden rytmittämää elämänmenoa tai koettaa aktivoinnin nimissä ylläpitää hiljaista rinnakkaineloa uuden talouden outsidereiden ja insidereiden välillä.

\section{Myös kilpailussa}

menestyjiä koskee kuitenkin se jännite, että työelämässä vaaditaan yhtä aikaa sekä uudenlaista joustavuutta että uudenlaista sitoutumista. Jännite on ongelma myös yrityksille ja ilmenee selvästi siinä, missä määrin ne ovat valmiita panostamaan työntekijöidensä koulutukseen, missä määrin odottavat julkisen vallan panostuksia. Joustavuuden ja sitoutumisen kaksinaisuuteen liittyy osaltaan kysymys refleksiivisyydestä. Kaikelle inhimilliselle toiminnalle ominaisena voidaan pitää toimijan kykyä ottaa etäisyyttä omaan toimintaansa ja tarkkailla sitä ja sen ehtoja samalla, kun hän kuitenkin sitoutuu tähän toimintaansa. Uutta ja ongelmallista sisältyy kuitenkin siihen, että oman toiminnan refleksiivinen tarkkailu ja samalla oman itsen peliin paneminen nousee nimenomaan markkinakilpailuun liittyvistä vertailun vaatimuksista ja on osa prosessia, jossa portfolio korvaa ammatin.

\section{Lopuksi otan esille}

tutkimusraportin avaamia näköaloja, jotka koskevat työkonseptin muutosta. Huomionarvoinen työkonseptin muutos liittyy kirjan läpikäyvään keskeiseen kysymykseen työelämän ja ammattikasvatuksen sukupuolittuneista käytännöistä. Kirjan yhteenve- toluvussa Anja Heikkinen pohtii kiinnostavasti, onko joustavuuden ja sitoutumisen uusissa monimutkaisissa yhdistelmissä kysymys työn ja siihen kasvattamisen naisellistumisesta vai miehisen logiikan globaalista voittokulusta. Voitaisiin väittää, että ideaaliksi on noussut eräänlainen uusi hybridi. Yleispätevyyttä edellytetään periaatteille, jotka aiemmin liittyivät joihinkin spesifeihin töihin. Yhtäältä on julistettu yleispäteväksi idea työn tuloksesta tuotteena eli tehdasteollisen "fordistisen" tuotannon periaate. Tämä ilmenee myös niin, että portfoliollaan työntekijä tai -hakija tuotteistaa itsensä.

\section{Toisaalta naisvaltaisten} palvelualojen periaate, asiakkaan, potilaan tai kasvatettavan tarpeiden huomioonottaminen, on laajennettu sellaiseen tuotantoon, jossa työntekijän suhde lopputuotteeseen ja sen käyttöarvoon on ollut vanhastaan etäinen. Tuotteistamisen ja asiakaskeskeisyyden yhdistävänä ideaalina on yrittäjyys. Ideaali ei tarkoita vain yrittäjäkunnan laajentamista, vaan myös yrittäjyyden periaatteiden, työ- tuntejaan laskemattoman yrittäjän toiminta- ja ajattelutapojen, viemistä palkkatyösuhteiden sisälle. Yrittäjyyden periaatteiden on määrä korvata sekä parjattu fordistinen palkkatyöläismentaliteetti että sellainen palvelu- ja hoivamentaliteetti, jossa oman työn tuloksia ei vielä oivallettu tuotteiksi. Jos ammattiidentiteetti onkin murenemassa, varsin kovat työyhteiskunnalliset normit näyttävät elinvoimaisilta.

\section{Viite}

Kirjoitus perustuu kommenttipuheenvuoroon raportin (Anja Heikkinen, Merja Borgman, Lea Henriksson, Mailis Korkeakangas, Leena Kuusisto, Pirjo Nuotio, Liisa Tiilikkala: Niin vähän on aikaa: ammatillisen kasvun katoava aika, paikka ja tila? Ammattikasvatuksen tutkimus- ja koulutuskeskus, Tampereen yliopisto 2001) julkistamistilaisuudessa Ammatillisessa opettajakorkeakoulussa Hämeenlinnassa 29.5.2001. Olen lukenut raportin paljolti niiden teemojen näkökulmasta, joita olen käsitellyt kirjassani Kansallinen työ. Suomalaisen suorituskyvyn vaalimisesta (Yliopistopaino, Helsinki 2001).

Pauli Kettunen 